\title{
An Arctic Execution: Private Charles B. Henry of the United States Lady Franklin Bay Expedition 1881-84
}

\author{
GLENN M. STEIN
}

(Received 6 January 2011; accepted in revised form 11 April 2011)

\begin{abstract}
Private Charles B. Henry, of the United States Lady Franklin Bay Expedition, was put to death by a summary military execution on 6 June 1884, at Camp Clay, near Cape Sabine, Ellesmere Land, in the High Arctic. An execution is an extremely rare event in Arctic and Antarctic history. Shrouded in mystery for over 125 years, Henry's execution has been told in two contradicting accounts. By considering the actions of key persons, presenting new details, and identifying related artifacts for the first time, the author concludes that the lesser-known account is likely more accurate and that the participants in the execution had their reasons for not sharing the actual version publicly until many years later.
\end{abstract}

Key words: Lady Franklin Bay Expedition, Charles B. Henry, Adolphus Greely, Brainard, Cape Clay, execution, International Polar Year expedition

RÉSUMÉ. Le soldat Charles B. Henry, de l'expédition américaine de la baie Lady Franklin, a été mis à mort lors d'une exécution militaire sommaire le 6 juin 1884, au camp Clay, près du cap Sabine, Ellesmere Land, dans l'Extrême-Arctique. Les exécutions se font extrêmement rares dans l'histoire de l'Arctique et de l'Antarctique. Entourée de mystère pendant plus de 125 ans, l'exécution du soldat Henry a été racontée dans le cadre de deux récits contradictoires. En tenant compte des gestes de deux personnes-clés, en présentant de nouveaux détails et en identifiant les artefacts connexes pour la première fois, l'auteur en conclut que le récit le moins connu est vraisemblablement plus exact et que les intervenants de l'exécution avaient des raisons de ne pas vouloir faire connaître publiquement la version réelle des faits pendant de nombreuses années.

Mots clés : expédition de la baie Lady Franklin, Charles B. Henry, Adolphus Greely, Brainard, cap Clay, exécution, expédition de l'Année polaire internationale

Traduit pour la revue Arctic par Nicole Giguère.

\section{THE LADY FRANKLIN BAY EXPEDITION}

In the years following the $1875-76$ British Arctic Expedition, it was suggested that nations should stop competing for geographical discoveries and instead dispatch a series of coordinated expeditions dedicated to scientific research. The causes behind the forces of nature could then be understood through observations in such fields as meteorology, oceanography, and geomagnetism, thus benefiting all peoples (Barr, 1985).

Eventually, 11 nations took part in the first International Polar Year (IPY) 1882-83, and the United States contributed two components to its first participation in an international scientific effort. In 1881, it was decided that the U.S. Army Signal Corps would establish one scientific station 500 miles from the North Pole, at Lady Franklin Bay, Grinnell Land (part of Ellesmere Land, later found to be an island) and another station at Point Barrow, Alaska (Barr, 1985).

Orders from the U.S. Army's Adjutant General's Office and the Office of the Chief Signal Officer established the Lady Franklin Bay Expedition (LFBE) under the command of First Lieutenant Adolphus W. Greely (Greely, 1888), with second lieutenants Frederick F. Kislingbury and James B. Lockwood. The 25-man Army expedition included two Greenlanders hired as hunters and dog sledge drivers.

The LFBE adopted the main features of a previous plan formulated by Signal Corps officer Captain Henry W. Howgate, which would eventually be voted down by Congress. First Lieutenant Gustavus C. Doane was to lead that planned expedition, and he specially selected 11 Second Cavalry men, including Sergeant David L. Brainard and Privates Francis J. Long, Julius R. Frederick, and Nicholas Salor. These four men later took part in the LFBE (Anon., 1880; Brainard, 1940; Bonney and Bonney, 1970; Guttridge, 2000).

This paper investigates the execution of Private Charles B. Henry on 6 June 1884, during the LFBE. By revealing the associations of the people involved and hitherto unknown details and related artifacts, the author presents a fuller picture than has been published to date of the two contradicting accounts of the execution. The new evidence is more supportive of the lesser-known account.

${ }^{1} 646$ Park Forest Court, Apopka, Florida 32703-1970, USA; eloasis@earthlink.net

(C) The Arctic Institute of North America 


\section{KEY PERSONS}

Adolphus Washington Greely (1844-1935) was born in Newburyport, Massachusetts. He entered the Civil War as a private, but ended the conflict with the temporary rank of major, awarded for faithful and meritorious services. He had been three times wounded in action. In 1867, Greely accepted a second lieutenant's commission in the Regular Army.

Greely joined the Fifth Cavalry in 1869. Having studied telegraphy, he alternated between the territories and detached service with the Signal Corps (building and maintaining telegraph lines) and duty with the Corps in Washington, D.C. This work led to an interest in sorting out weather information, which in turn led to the serious study and application of meteorology.

Along with his scientific background, Greely was physically tough and able to command men during the adversity and hardship of active military service and to manage men working in specialized military fields. Greely's numerous original and copied journals are stored at various private and public repositories, with gaps in entries and sometimes on loose sheets of paper.

David Legg Brainard (1856-1946) was born in Norway, New York. When he joined the Army in September 1876 (Fig. 1), it had been only three months since Custer's command was defeated. Custer divided his command, but many soldiers under three of his officers survived the battle at the Little Big Horn. Brainard was rushed westward and served with Company L, Second Cavalry, in the 1877-78 campaigns against the Northern Cheyenne, Sioux (during which he was wounded), Nez Perce, and Bannock Indians. During the Bannock uprising, Brainard served under Lieutenant Doane.

Brainard firmly believed that orders clearly issued should be obeyed; he was promoted to corporal in December 1877 and to sergeant in August 1879 (Brainard, 1938).

Upon joining the LFBE, Brainard was chosen as First Sergeant (chief of enlisted men) and Commissary Sergeant. A good hunter during the LFBE, Brainard had acquired expert marksmanship skills during the Indian campaigns by hunting buffalo after hours.

Over many years, Brainard compiled a variety of official documents and newspaper and magazine articles relating to himself and the LFBE. A very organized and meticulous individual, he also possessed an excellent memory. Brainard's LFBE writings exist in three forms: pencilled field notes, inked journal (three volumes), and published writings based on the inked journal. When the expedition left St. John's, Newfoundland, for the Arctic in July 1881, Brainard began making daily entries in field notebooks; his nearly three years of field notes form a record unique among LFBE personnel.

Sergeant Francis Joseph Long (1852-1916) was born in the Kingdom of Württemberg (now Baden-Württemberg, Germany); in fact, several expedition members were German-born. He evidently joined the Army in the early 1870s and served in the Sioux campaign. During the 1877

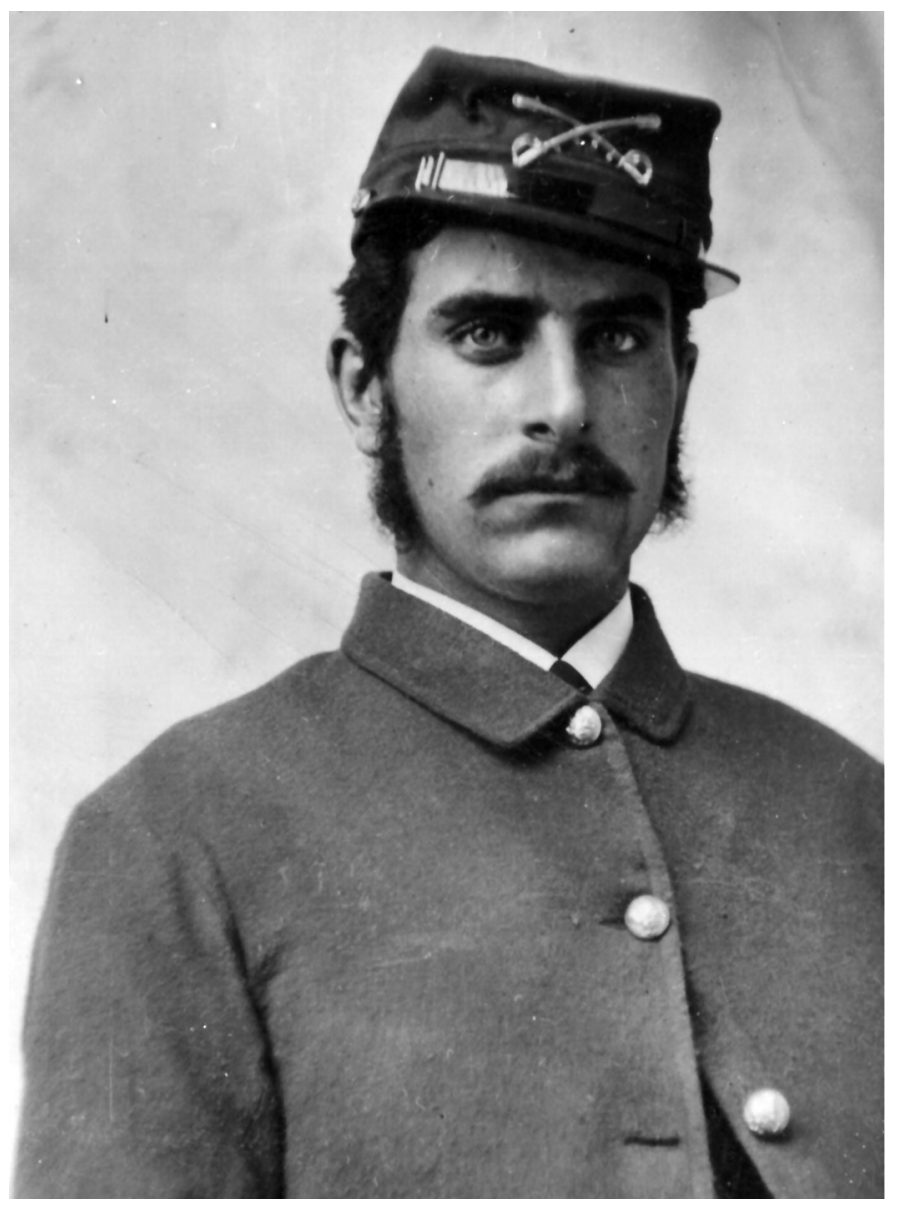

FIG. 1. Private David L. Brainard, U.S. Cavalry, September 1876 (courtesy of Jerome A. Greene).

Nez Perce campaign, he was under Lieutenant Doane in Company G, Second Cavalry. When he volunteered for the Howgate expedition three years later, Long was still in the Second Cavalry, but at some point prior to the LFBE, he must have transferred to Company F, Ninth Infantry.

Long joined the LFBE as a private and established a fine hunting record during the expedition. He was conditionally promoted to be sergeant in April 1884 for his "coolness and skill" during the killing of a bear (Greely, 1894:671). The author has never seen or heard of any original or copies of journals for Francis Long.

Sergeant Julius R. Frederick (1852-1904) is recorded as "Fredericks" in various sources, but for purposes of consistency, the former will be used here. One source indicates Frederick was born of German parents in Dayton, Ohio, but another states he was born in Germany. His nickname among his Arctic comrades was "Shorty" because of his five-foot, two-inch stature (Frederick, 1874-1978). Expedition officer Lieutenant James B. Lockwood further summed up their views of Frederick's humanity, writing that he was "a man of feeling and a hater of jokes" (Lanman, 1893:210).

Frederick joined the Second Cavalry in September 1876 (evidently as part of Company L), fought in the Sioux and Nez Perce campaigns, and served under Lieutenant Doane 
during the Bannock uprising. A saddler by trade (Lanham, 1893), as far as can be determined, Frederick did little hunting during the LFBE, but performed the various duties of a cook, steam-launch engineer, and shoemaker. Though Frederick joined the expedition as a private, Brainard recommended he be conditionally promoted to sergeant in March 1884 for his very creditable performance of engineering duties in the steam launch (Greely, 1894).

A journal by Frederick, held by the Indiana Historical Society, consists of one volume covering 1881-82, as well as two other undated documents (totaling three written pages) catalogued as "Midwinter" and "The Arctic Midnight" (Frederick, 1874-1978; E. Mundell, pers. comm. 2010).

Private Charles B. Henry (1856-84) was born in Hanover, Germany (Anon., 1884b) as Charles Henry Buck. Henry worked in the print shop of the Daily Monitor, in Moberly, Missouri, under the name Charlie Buck. In 1876, he joined Company G, Seventh Cavalry. Company G had a less than desirable reputation for its lack of discipline, and the men of Fort Buford (Montana Territory) usually referred to it as the "Forty Thieves" (Mackintosh, 2002:124). Some sources state that Buck served under Major Reno at the Little Big Horn, but this is not correct, so Buck must have been with the unit after the Custer fight.

Buck was made company clerk, and in 1878 he was confronted with evidence that he had forged the signature of his company commander (First Lieutenant George D. Wallace) on orders of whisky and other articles. He confessed to his crime and was sent to prison. After serving one year of his sentence, Buck was released (or escaped) and turned up in Deadwood, Dakota Territory, where he killed a Chinese man in a gambling brawl.

Buck then enlisted in the Fifth Cavalry under the alias Charles B. Henry, serving in Company E. Using this name, he wrote to Greely from Fort Sidney, Nebraska, in April 1881 , volunteering for the expedition. Henry had the strong recommendation of his company commander, Captain George T. Price, to back him up.

This was no ordinary endorsement to Greely, who had been friends with Price since 1877, so naturally he leaned toward taking Henry (who repeatedly telegraphed Greely with reminders of his availability). The LFBE leader made a place for Henry, who joined the expedition in June, having made arrangements with the Chicago Times to act as the Times' special correspondent with the expedition.

Another source states that Henry, who came to join the LFBE from Fort Sidney, was not one of the men originally chosen, but took an opportunity that presented itself when one of the original members deserted just before the expedition left the United States. As far as the author is aware, however, there was only one desertion from the LFBECorporal Paul Grimm, Eleventh Infantry, sometime after 17 June 1881 - who was replaced by Private Roderick R. Schneider, First Artillery (Greely, 1888, Vol. 1). Supposedly, since Henry was the only volunteer from the Fifth Cavalry, with a strong recommendation from post commander Lieutenant Colonel Compton, Greely decided to take him.

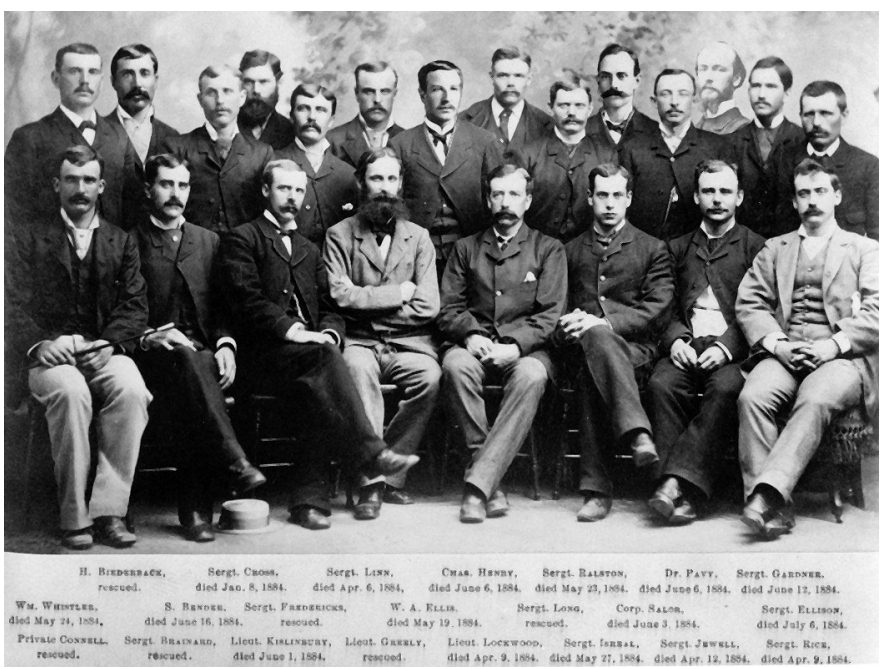

FIG. 2. Most members of the LFBE in June 1881. Henry is in the back row, just to the right of center. The head of Dr. Octave Pavy (rear, third from right) was pasted in some time after the original photograph (National Archives and Records Administration [NARA]).

A group photograph taken of LFBE members just prior to sailing north was published in Harper's Weekly (Fig. 2) (Todd, 1961:xx-1). When some Seventh Cavalry officers (perhaps even Wallace) saw the magazine at a western Army post, they recognized the "Henry" in the photograph as Charles Henry Buck. A report regarding Henry was made to the War Department, and if he had returned from the Arctic he would have answered for his wrongdoings (Brainard Papers, 1881-84; Price, 1883; Anon., 1884e; Copley, 1911a; Todd, 1961; D. Kosman, pers. comm. 2010).

The "biggest man and heaviest eater in the party (he put on twenty-five pounds at Fort Conger)" (Todd, 1961:123), Henry was also a crack shot.

Henry's leatherback journal, written in ink and covering the dates from 26 December 1881 to 8 August 1882, exists in the Explorers Club archives. In addition, two folders at the National Archives (RG 27) contain contemporary copies of unidentified journal pages. One folder has papers covering 25 December 1883 to 15 May 1884 that are believed to be Henry's (as noted on the folder and file). The entries therein compare favorably with the translation of a journal written in German and documented as originating from Henry's descendants in Germany. The other folder is marked "from Henry? diary" (Henry, 1883-84), and the papers appear to cover part of the period from 14 May to 4 June 1884, but the entries are at variance with those in the German journal.

\section{THREE YEARS OF ARCTIC SERVICE}

By the end of August 1881, a frame house, measuring $65 \times 21 \times 14$ feet, was constructed at Lady Franklin Bay and named Fort Conger. Over the next two years, though detailed scientific data were collected, official instructions also stated that "sledging parties will generally work in the 
interests of exploration and discovery" (Greely, 1888, Vol. 1:99). The LFBE planted the Stars and Stripes in unknown lands, discovered many new geographic features, and set north, east, and west "farthest" records with sledge parties that included Lockwood, Brainard, and Greenlander Thorlip Frederik Christiansen (Greely, 1888, Vol. 1; Todd, 1961).

Because of mismanagement of resupply expeditions from the United States, expedition members initiated a planned retreat by boat to Cape Sabine, 225 miles to the south. However, the journey turned into a nightmarish "seven weeks of hardship and sometimes sheer terror, over a distance totalling some 500 miles by sledge, boat, or while helplessly adrift" (Guttridge, 2000:216).

On 29 September 1883, the party reached terra firma once more at a place across from Littleton Island. Greely named the spot Eskimo Point, after the discovery of three ancient igloos. In early October, Greely predicted a dark future: "I looked forward to privation, partial starvation, and possible death for a few of the weakest..." (Greely, 1894:540).

The party moved to Cape Sabine, several miles to the northeast, which entailed heavy sledge work as the thermometer steadily moved from $0^{\circ}$ to $-13^{\circ} \mathrm{F}\left(-18^{\circ} \mathrm{C}\right.$ to $\left.-25^{\circ} \mathrm{C}\right)$ and kept falling. At Cape Sabine the men constructed a stone house for the winter, with an upturned boat for a roof. It was christened Camp Clay and measured only $25 \times 18 \times$ 4 feet.

Throughout the following months, the men's spirits and energy dwindled, and constant hunger was now their companion. Worse, food was being stolen from the commissary storehouse. More than once, angry accusations flew from long-bearded faces, blackened by soot from the cooking fire. Using scales made from scrap material, Greely and Brainard "weighed out the supplies and made their calculations, carrying the daily ration of each type of food to two decimal places - hundredths of an ounce" (Todd, 1961:129). The party engaged in storytelling to pass the time, but nothing could really take their minds away from the hunger tearing at their stomachs.

The first death occurred on 18 January 1884. In spite of the privations, only one man died that winter, even though scurvy was also present.

With the coming of spring, Brainard rigged a cloth net to catch "shrimps" or "sea fleas," tiny crustaceans about the size of a wheat grain. Both Brainard and Sergeant George W. Rice (a Canadian) made use of the rig in a tidal crack. The two worked earnestly to supply food to the party and so were acutely affected by any thieving: "I talked to Brainard today and cautioned him to look out for the commissary as it is greatly to be feared that certain of the party cannot be trusted in case we come to extremes. I have my eye on a gun and will not hesitate to use it if occasion requires it" (Rice, 16 March 1884:13).

Shortly before dinner on 24 March 1884, Charles Henry vomited half-chewed raw bacon he had stolen earlier the same day. The next day, an informal trial was held. During his time at Fort Conger, Henry was the originator of many profane remarks, misdeeds, and lies, so Greely and others had learned not to trust him-now, even Henry's friends among the malcontents turned against him. It was further found that the culprit had gotten in line twice for an issue of rum on the day of the incident.

As Greely recalled, "Commencing with [Henry's] own friends and sleeping companions, each man in turn pronounced him guilty. There was much suppressed talk of proceeding to violence, but I simply remarked that it was a military command, and that I would take extreme measures when needful" (Greely, 1894:654). But Greely was in a quandary. He had not taken action in another situation when Dr. Octave Pavy stole food, on the grounds that the doctor's services were essential to everyone's welfare. Consequently, Greely relieved Henry of duty, and confined him, unless supervised by someone while outdoors, to his sleeping bag (Greely, 1894; Todd, 1961). Henry was effectively ostracized over the coming weeks.

In his field notes, Brainard set down a comrade's thoughts: "Rice stated the case very clearly \& suggested that [Henry] be confined as a prisoner" (Brainard, 18701961, No. 11 field notebook, 25 March 1884:125). Rice, who had put his life at risk several times for the party's benefit and netted shrimps in sub-freezing temperatures, wrote in his journal that day, "I opened the ball on Henry and everything is satisfactorily arranged, though I think we would have been justified in putting him to death" (Rice, 25 March 1884:18-19).

On 9 April 1884, Brainard took an inventory of provisions and calculated that they would not last beyond 10 May (Brainard, 1940).

On 14 April, Greely wrote in his journal that should anything happen to him, Brainard was to succeed him in command of the expedition (Greely, 1894). On 22 April, Greely added, "I gave Sgt. Brainard instructions about my effects \&c. if anything should happen to me. I want Brainard commissioned" (Todd, 1961:214). By this time, the daily nourishment per man was only 12 ounces of meat and two ounces of bread, plus some shrimp and weak tea-and later it dropped further. Brainard continued to bear the full responsibility for every ounce of provisions issued.

Though Henry was eventually paroled by Greely and allowed to move around the hut, 27 April saw him return to his familiar ways, as Brainard recorded: "Henry brewed the issue of alcohol without authority \& stole enough of the precious fluid to get thoroughly and disgustingly drunk. He is a born thief as his 7th Cavalry name will show-a perfect fiend" (Brainard, 1870-1961, No. 11 field notebook, 27 April 1884:182).

To date, LFBE historians have consistently written that no one on the expedition knew of Henry's criminal history, but Brainard's daily notes plainly show otherwise, and this information was later edited out of published versions of Brainard's journal (Greely, 1888, Vol. 1; Brainard, 1929, 1940). Since Brainard was First Sergeant, it can fairly be assumed that Greely (and perhaps others) also came to possess the same knowledge. In consequence, although others 
also stole food, Henry would have been treated with less tolerance. Conversely, it is possible that Henry never believed the ultimate punishment would be used against him.

However, even Henry himself hinted at his personal failings. In early May, he wrote a postcard to his old commander (Captain Price): "Captain: Only six more days provisions are left us. Starvation looks us in the face. Seven of our party are dead already and the rest of us are resigned to follow. The expedition has been a success but I have unfortunately not been" (Todd, 1961:223).

With the daily allowance reduced to the minimum, and more accusations and counter-claims of stealing food hurtling around camp, it was difficult to know whom to trust.

By 15 May, Greely wrote that "sea-kelp and shrimps form our only food from to-day, until we are driven to eating the seal-skins" (Greely, 1894:686). Items like saxifrage and reindeer moss (a lichen) would also become a necessary part of the starving men's diet. Toward the end of the month, for the coming summer, the hut was abandoned in favor of a wall-tent, some 300 yards to the southeast: only 14 men remained alive.

Wednesday, 4 June 1884 - "Henry stealing again from our shrimps. Schneider and Bender also suspected. It will be necessary to take some severe action, or the whole party will perish" (Greely, 1894:697). Extreme measures were thrust upon Greely.

\section{LAST RESORT}

By 5 June 1884, the survivors' situation was spiraling downward ever faster, and Henry again admitted to stealing food. "He promised to deal fairly in the future, and seemed impressed with my caution that he would come to grief if he did not. I felt doubtful of his sincerity, however, and consequently have given the following written orders" (Greely, 1894:698-699):

Near Cape Sabine, June 5, 1884.

To Sgts. Brainard, Frederick \& Long:

Pvt Henry having been repeatedly guilty of stealing the provisions of this party, which is now perishing slowly by starvation, has so far been condoned and pardoned. It is however imperatively ordered that if this man be detected either eating food of any kind not issued him regularly or making caches or appropriating any article of provisions you will at once shoot him and report the matter to me. Any other course would be a fatal leniency the man being able to overpower any two of our present force.

A.W. Greely

Lt. \& ASO. \& Asst

Cmdg L.F.B. Expd

(Greely, 1884a; Fig. 3)

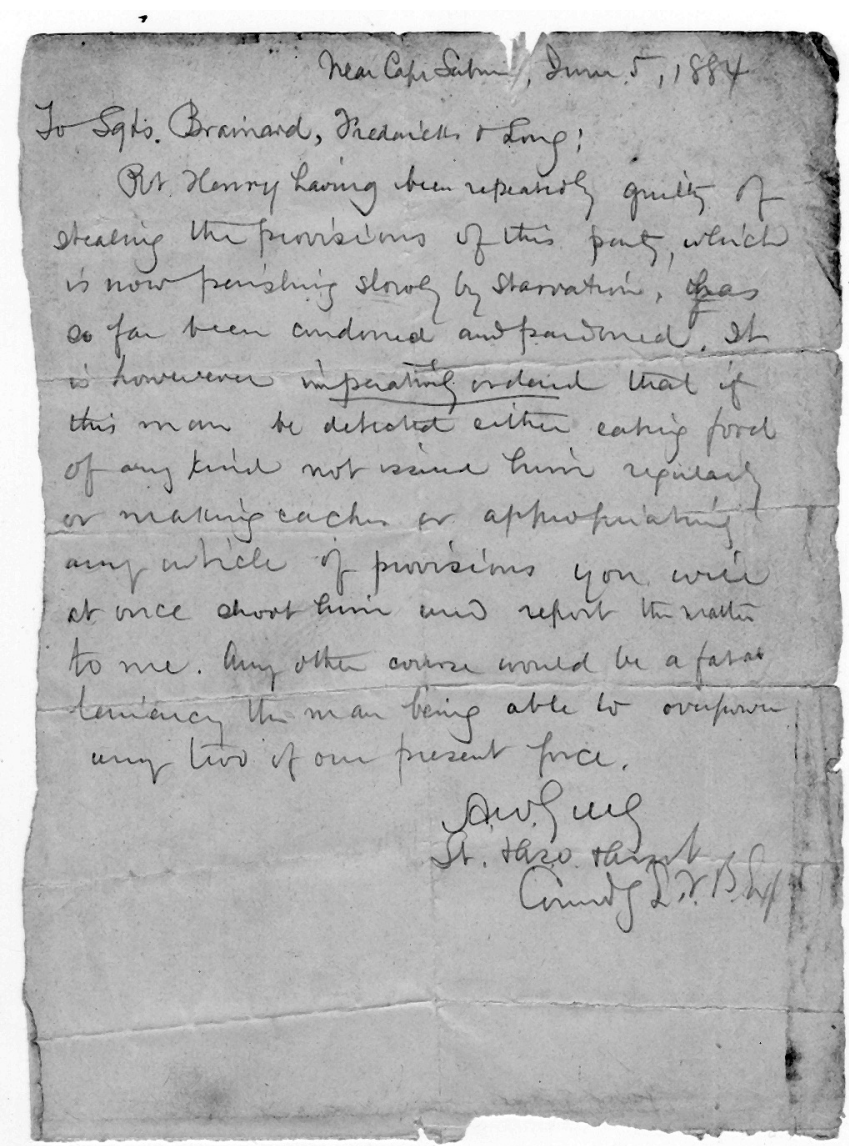

FIG. 3. Greely's shoot order, 5 June 1884 (courtesy of Dartmouth College Library).

In the 5 June entry of his field notebook, Brainard wrote of Henry's continued thieving and that "the C.O. issued an order to Long, Fred, \& myself to shoot him if any other acts of a like nature be repeated" (Brainard Papers, 1870-1961, No. 11 field notebook, 5 June 1884).

After Henry was caught stealing the shrimps, Greely (1894:699) wrote:

Later Henry made two trips to our old winter-quarters [the hut], and when returning from the second trip, while passing me, I stopped him and questioned him as to what he had been doing, and what he had with him. After a while he admitted he had taken from there, contrary to positive orders, seal-skin thongs; and, further, that he had in a bundle, concealed somewhere, seal-skin. He was bold in his admissions, and showed neither fear nor contrition. I ordered him shot, giving the order in writing:

Near Cape Sabine June 6, 1884.

Sgts. Brainard, Long and Frederick:

Notwithstanding promises given by Pvt C.B. Henry yesterday he has since as acknowledged to me tampered with seal thongs if not other food at the old camp. This 


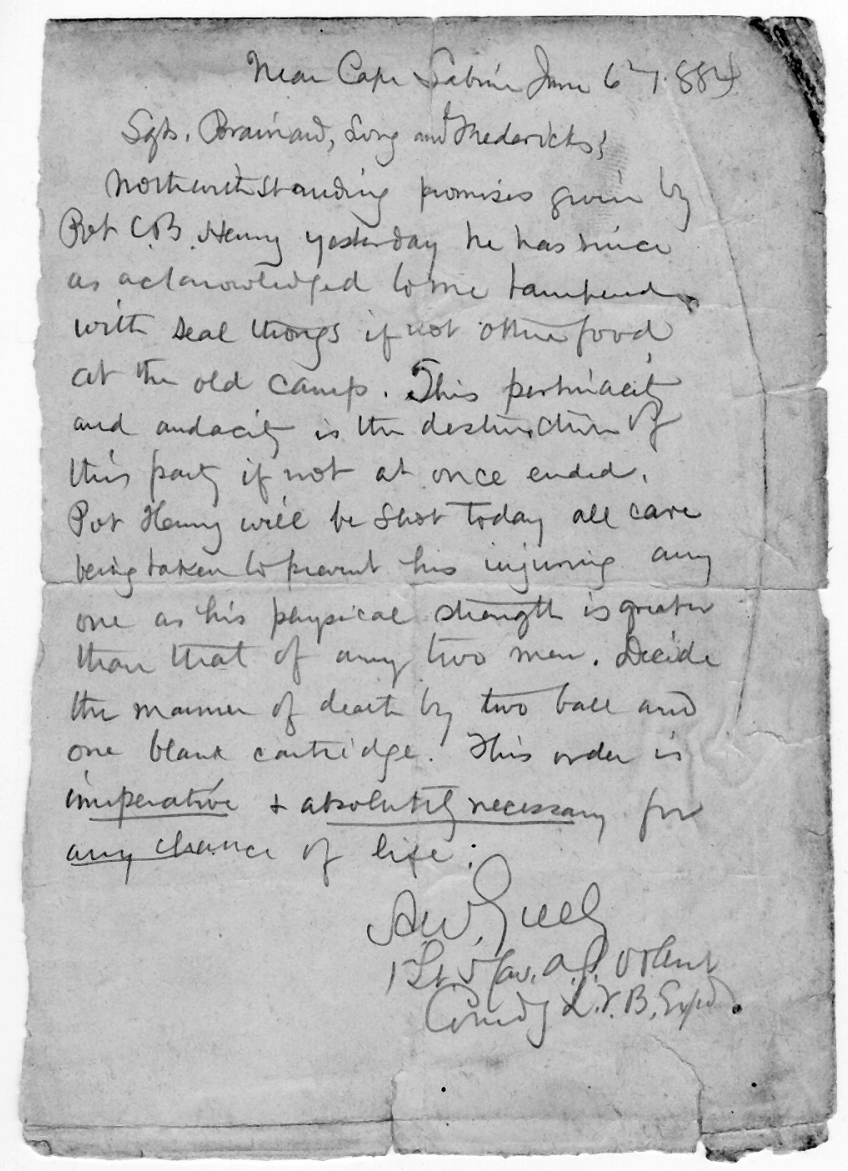

FIG. 4. Greely's execution order, 6 June 1884 (courtesy of Dartmouth College Library).

pertinacity and audacity is the destruction of this party if not at once ended. Pvt Henry will be Shot today all care being taken to prevent his injuring any one as his physical strength is greater than that of any two men. Decide the manner of death by two ball and one blank cartridge. This order is imperative \& absolutely necessary for any chance of life.

$$
\begin{array}{r}
\text { A.W. Greely } \\
\text { 1 Lt. } 5 \text { Cav. A.S.O \& Asst } \\
\text { Cmdg. L.F.B. Expd } \\
\text { (Greely, 1884b; Fig. 4) }
\end{array}
$$

Brainard left blank spaces in his No. 11 field notebook for Greely's orders of 5 June 1884 (this stated by Brainard to be a copy) and 6 June 1884; in a 1935 newspaper interview, he said he still had the execution order. Notebook No. 11 and the two orders - both in Greely's hand - were in the possession of Brainard's stepdaughter when Todd examined them while researching his book Abandoned (Brainard, 1870 - 1961; Anon., 1935).

When Brainard received the fateful order from the commander's hand, he read it and showed it to Frederick. Then the two moved casually in the direction from which they expected Long to appear. Somewhat later Greely, lying in the tent with the flap open, could see them meeting the hunter a few hundred feet away. For a while, the trio seemed by their gestures to be engaged in a dispute. Then the commander was relieved to see two of the figures move downhill toward the abandoned winter quarters, while the third walked in another direction. Whatever their point of discord, they seemed to have settled it (Todd, 1961:242).

Greely's Three Years of Arctic Service and his official Report offer very meager information, indicating only that he had chosen "three of the most reliable men" (Greely, 1888, Vol. 1:363), that at about two o'clock on 6 June, shots were heard, and that later, the execution order was read to the party (Greely, 1888: Vol. 1, 1894).

On that fateful day, Brainard recorded only a few terse remarks regarding the execution in his field notebook: "A further confession on the part of Henry to the C.O. of stealing shrimps this morning from the stew caused the C.O. to issue the following order [blank space for Greely's order] No further explanation on this matter is necessary. The order was duly executed at 2 p.m." (Brainard, 1870-1961, No. 11 field notebook, 6 June 1884). And this is all that Brainard wrote about the execution at the time.

Private Biederbick also recorded his observations of that day:

Brainard, Frederick, Long \& Henry went down to the old hut to get some wood about 2 o'clock. Shortly afterward we heard several shots there. Brainard, Frederick \& Long returned abt. Three o'clock. The Commdg Officer ordered Sergt Brainard to turn over several orders to me, \& me to read them aloud \& thin [sic] return them [Biederbick went on to describe the contents of the orders].

(Biederbick, 1883-84, 6 June 1884)

And that was all that records would reveal. Greely received no detailed report of how Henry died, nor did he demand any. Of precisely how Henry died, of any farewell utterance or plea for mercy, of even the exact site where his body had been left, there was, officially, nothing. Greely's only comment at the time was that the body would be interred at the foot of the northern ice field. And he added that, had he not been weak and confined to his sleeping bag, "I should myself have killed Henry" (Guttridge, 2000:273). Further evidence of Henry's misdeeds was uncovered when his bundles were searched, and though the stealing of food was hardly confined to the executed man, "Henry was the only one who was bold in his thefts, acknowledging them with audacity" (Greely, 1894:703).

The day after Henry's death, Private Roderick R. Schneider wrote, "Brainard said he spent [a] very pleasant night \& rested better than he has for many weeks" (Schneider, 7 June 1884).

Article 87 of the U.S. military's Articles of War states: "No person shall be sentenced to suffer death but by the concurrence of two-thirds of the members of a general court-martial" (Benét, 1862:354). However, any military 


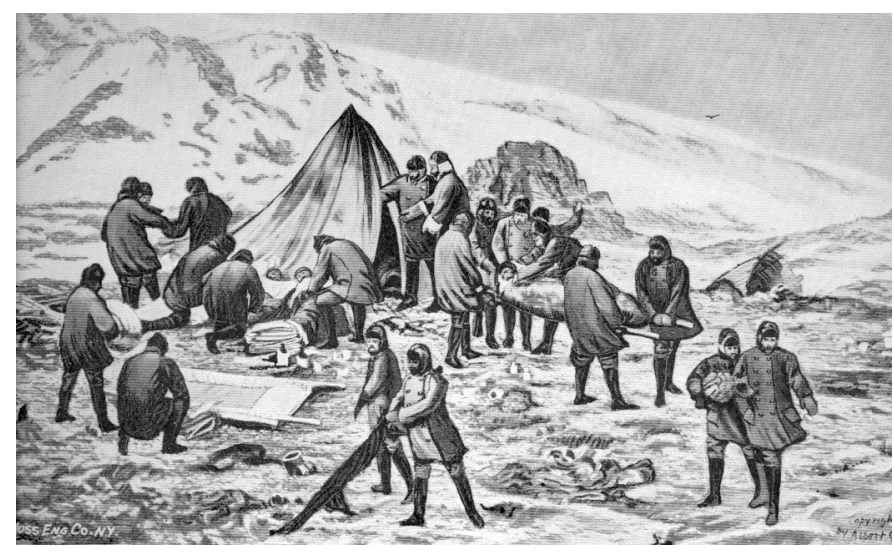

FIG. 5. Rescue of the Greely Party (1885), an official painting by Albert Operti. The War Department detailed Brainard to assist Operti with details; Greely and Biederbick also assisted (Brainard, 1940).

officer operating in the field possesses a fair degree of discretion-even greater if that officer lacks the ability to communicate with superiors-in carrying out orders. In spite of extreme deprivation, Greely's command decisions regarding Henry followed an incremental course that led to his ultimate decision to execute Henry in order to preserve lives.

Greely's choice of two balls and one blank cartridge referred to two cartridges, plus a blank cartridge (i.e., minus the bullet), and followed the usual custom with firing squads. This raises the psychology at work during an execution. The intention was that none of the firing squad members would know who had the blank cartridge. In addition, afterward, this process allowed each member to believe it was possible that he did not fire the fatal shot. "The need for such customs shows that we are all prey to our subconscious ideals" (Lazell, 1920:232). The effects of firing squad duty obviously prey upon the conscious mind as well. Decades later, Brainard reflected on this very point, declaring that "no matter what the provocation, the family of a man doesn't want to think of him as an executioner" (Anon., 1935). In a later interview, he initially closed the door on a reporter: "Oh yes, I remember the event, just as though it happened yesterday, but it is one of those things a man doesn't care to talk about" (Hazen, 1941). Brainard's thoughts were not confined to the taking of human life. When asked about his outdoor recreations in 1904, he spoke of fishing and taking walks in the country and in parks, using a camera when it was worthwhile, adding that he would "rather shoot something with a camera than a gun" (Whitney, 1904:223-224).

A somewhat similar execution scenario, also an attempt to preserve the lives of starving men, had played out during Sir John Franklin's 1819-22 Arctic Land Expedition. A detachment of four men from the expedition, including Surgeon John Richardson, discovered that their comrade, Midshipman Robert Hood, had been murdered by an Iroquois voyageur, Michel Teroahauté (also known as Ferohaite). Under the circumstances, Richardson shot Michel to save their own lives (Franklin, 1824, Vol. 2).

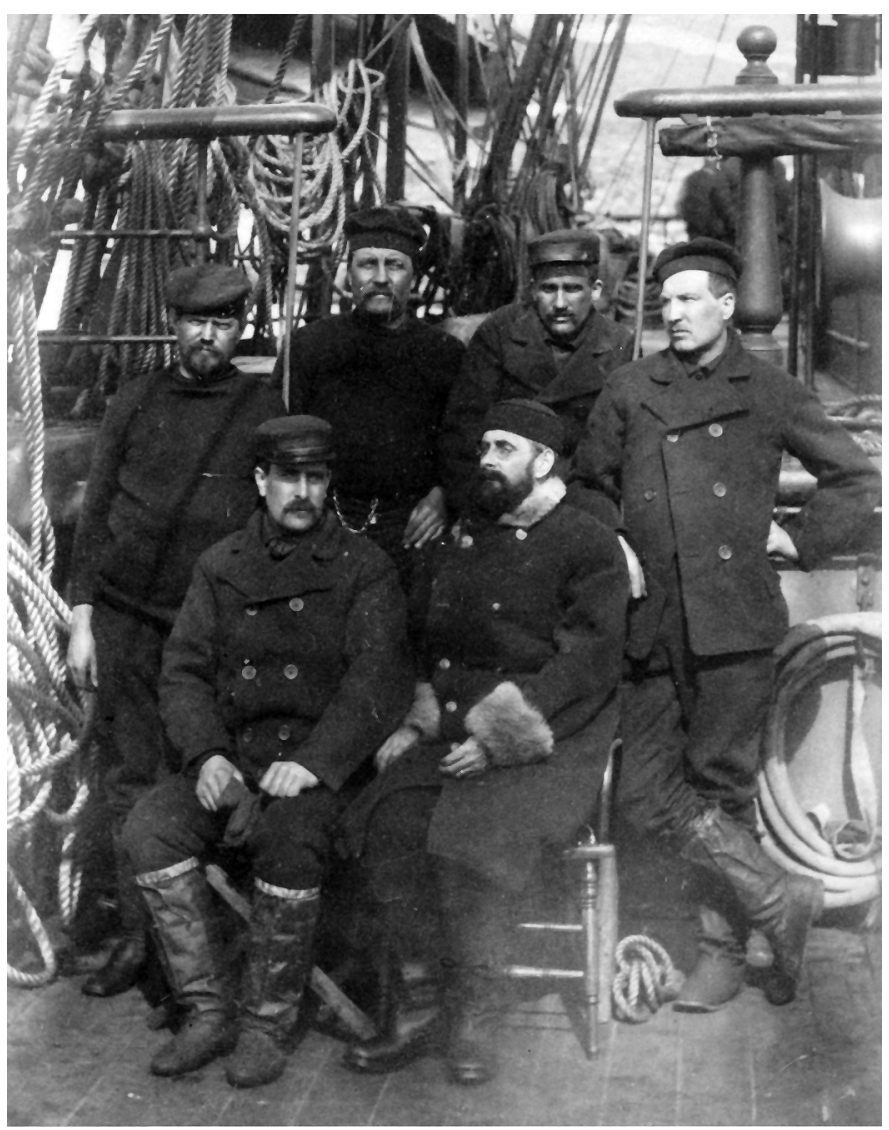

FIG. 6. The six LFBE survivors on the way home in 1884. Standing, left to right: Long, Frederick, Connell, and Biederbick; seated, left to right: Brainard and Greely (NARA).

Finally, on 22 June 1884, just seven men - all that was left of the LFBE - were found barely alive (Fig. 5) by a naval rescue squadron of four ships, the USS Thetis, the USS Bear, the Alert (on loan from the Royal Navy), and the SS Loch Garry (chartered to take coal to Littleton Island). One more man died on the way home, and the six survivors (Fig. 6) arrived at Portsmouth, New Hampshire, on 1 August.

Brainard had charge of all the expedition's journals during his homeward voyage on the Thetis (Guttridge, 2000); Long and Frederick left Cape Sabine on the Bear (Copley, 1911b). During the passage, Brainard wrote up in ink an incomplete journal from field notes, keeping his notebooks concealed in a small wooden chest that he eventually donated to the National Museum of American History (NMAH) (Brainard, 1938).

Just over a month later, a firsthand, but fantasy, account of Henry's execution was published. Julius Frederick's interview by a Daily News reporter first appeared in Indiana's Fort Wayne Sunday Gazette (Anon., 1884c); immediately afterward, it was published in greater detail in The New York Times:

As to the shooting of Henry, Frederick said: "The party became a unit against him and demanded that Greely should issue a death warrant or allow it to proceed 
without [a reference to the outcome of the 25 March informal trial]. Greely finally consented, and the order was secretly issued. Now, mind you, Henry was as supple as ever, and if he had known that an order for his death had been issued he would have killed us all, for we were so weak that we could not defend ourselves and could barely walk with a gun. Three guns were loaded - I can't tell who loaded them - two of them with balls, the other with a blank cartridge. The three were placed on the ground and an equal number of men detailed to take them up for the execution. Brainard, Long, and myself were the three. We did not know who loaded the gun with a blank cartridge. Nobody knows except the man who loaded it. We were then ordered to proceed to the execution. We found Henry down on the coast and alone, about 150 yards away, in the very act of collecting seal skins which were designed for the subsistence of the entire party. Henry did not know that we were about to kill him, but he knew that he had been warned time and again that he would be killed if he persisted in appropriating the food of the party. We walked to within 20 yards of him, and the ranking man [Brainard] said: 'Henry, we are now compelled to carry out our orders.' The order to fire was given, and the man dropped dead. There was no missing him at that range, and the aim from each of the two men, whoever they were, who carried bullets in their guns, was fatal. Henry did not say a word before or after we shot. (Anon., 1884d)

The Sunday Gazette story contains one detail that does not appear in the Times: a claim that Henry was shot in the back (Anon., 1884c). What is significant about Frederick's description is that the details and sequence of events amount to a "textbook" execution, amid far less than ideal circumstances. Everything is neatly laid out, and it reads like a perfect scenario-in fact it's too perfect. Earlier in the Times article, Frederick refuted "the statement that there were two factions in the Greely party. I never saw a party so united and harmonious as was the Greely party. The only man who ever disobeyed an order was shot." Publicly, Frederick wished to paint a straightforward picture: Henry was the sole guilty man, and he was executed per Greely's order. However, the details of Frederick's version of the execution are entirely different from those contained in a later version recounted by Brainard and Long, and they do not coincide with information that subsequently surfaced.

\section{WITH THE PASSAGE OF TIME}

A second version of the execution was told to journalist Frank B. Copley on the night of 18 December 1906, when he interviewed Brainard, Long, and Biederbick; Frederick had died in Indianapolis two years before (Anon., 1904). The scene was an Arctic Club banquet held in the rooms of the Aldine Association, on Fifth Avenue in New York City (Anon., 1906).
At the time he spoke with three of the LFBE survivors, Frank Barkley Copley (1880-1968) was a journalist and the author of several articles and short stories. That he was allowed to attend the Arctic Club banquet and carry out interviews among such an exclusive group during a celebratory occasion indicates that Copley was probably regarded as a serious journalist. In addition, it is known that Copley referred to both published and unpublished material, and Part 1 of his LFBE article did not see print until four years after the interviews.

By 1906, 22 years had passed since the execution, so neither Brainard nor Long (let alone Biederbick) had any reason to make up a story about what had happened that day in June 1884. In fact, this version of the execution provided clues that enabled the present author to uncover supporting evidence by identifying certain details that also exist within other sources and by drawing upon LFBE artifacts. Copley subsequently published an article on the LFBE in three parts, each with subtitles, in The American Magazine between December 1910 and February 1911. The editor's note, at the beginning of the first installment, states that the writings were "drawn not only from the published documents but from personal talks with survivors and private journals hitherto unpublished" (Copley, 1910):

Sergeants Brainard, Long, and Frederick could not, as ordered, "decide the manner of death by two ball and one blank cartridge"; Greely had failed to take into consideration that at the time, the party had only one serviceable rifle left.

The three sergeants drew lots to see who would do the shooting. When they had done so, they bound themselves with an oath that the identity of the man thus chosen never should be revealed.

Henry was at the tent on Cemetery Ridge with all the other men, when the time for putting him to death came. What was to take place of course was known only to the three sergeants and the commander. Two of the sergeants remained in the vicinity of the old hut, while the third [Frederick] went up to the tent to bring Henry down.

The man who went for Henry told him that he was wanted at the old camp to help carry up some more of the supplies that had been left there. Suspecting nothing, Henry readily accompanied the sergeant to the place chosen for putting him to death.

Now, Greely had repeatedly cautioned the three sergeants to take no chances on Henry's getting away; for, although none at Cape Sabine knew the man's past history as we presently shall know it, enough of the man's black soul had been revealed to make his comrades feel that no crime could be put past him.

So Brainard, Long and Frederick, cautioned by their commander and warned by their own knowledge of the man with whom they had to deal, had decided that Henry should be made to stoop to pick up something, and that then he should be shot from behind. At least 
one of the sergeants had no more compunction about killing him than he would have had about killing a mad dog.

But one of the other two men weakened at the last moment. To shoot a man in cold blood from behind, to send him into eternity with no opportunity to compose his soul, was too terrible a thing for him to stand. It was a mistake that nearly proved disastrous.

Henry was told, face to face, that he was to be put to death in accordance with the order of the commander, and he was advised to kneel and make his peace with his God. At the same time, the executioner appeared with his rifle at a convenient distance, before the doomed man's eyes.

Henry stood agape. He muttered something about not being right. Near where the third sergeant stood an axe lay on the ground. Henry's gaze, searching the ground, encountered the axe. He sprang for it. A warning cry was raised. The sergeant who stood near the axe jumped and got his foot on it, almost as Henry was upon him. There was a cry of "Quick!" Even then there was danger of the executioner shooting his fellow sergeant, if his aim was the least unsteady.

But, despite all he had been through, the aim of the executioner was true. The rifle cracked, and the bullet sped, penetrating the breast of the man for whom it was intended when it was molded. Henry whirled, crying: "You have tricked me! You have tricked me!" Again the rifle cracked. The second bullet went through Henry's head, and he fell dead.

Henry was put to death about two o'clock in the afternoon [6 June 1884].

(Copley, 1911a)

\section{AMMUNITION, GUNS AND AN AXE}

At this point, a brief overview of some ammunition vocabulary is in order. A cartridge is made up of a bullet, gunpowder, and primer within a single metallic case, precisely made to fit the firing chamber (the portion of the barrel in which the cartridge is inserted prior to being fired). A cartridge without a bullet is called a blank. Cartridges come in different calibers, the caliber being the approximate diameter of a gun barrel and the neck of the cartridge used in it. For example, the bullet of a $.45-70$ caliber cartridge measures 0.45 of an inch in diameter.

At the start, the LFBE had a "liberal and excellent supply of arms and ammunition" (Greely, 1888, Vol. 1:2). Though the author has not been able to locate a detailed list of items, the LFBE supply was probably similar to that of Howgate's expedition: "Six (6) Springfield rifles. Six (6) shot-guns. Six (6) revolvers, with necessary ammunition" (Case, 188081:687). Upon abandoning Fort Conger on 9 August 1883, the party carried south "four rifles, with about a thousand rounds of cartridges, and two shot-guns, with ample ammunition" (Greely, 1894:436).
One month after the party reached the vicinity of Cape Sabine in September 1883, "[i]n order to husband our ammunition and insure our obtaining game," Greely ordered that Lieutenant Kislingbury, Sergeant Long, and the two Greenlanders be considered the hunters, "and that others should serve only on special occasions" (Greely, 1894:532). Over time, concern about the ammunition supply increased, and the customary military salute was not fired over the graves of Cross and Linn (Greely, 1894; Guttridge, 2000).

Brainard ensured that all manner of expedition artifacts were kept together, including other members' personal items, and at some point he labeled them using his calling cards. He donated these artifacts to the NMAH in 1938 (D.E. Kloster, pers. comm. 1995), and on a typewritten accession list (which was compiled without catalogue numbers) is found: "CARTRIDGE, $.45 \mathrm{cal}$., held as a reserve for the execution of Henry at Fort Conger [sic]" (Brainard, 1938). This could have been a $.45-70$ Springfield or .45 Colt.

At first, the wording "the execution of Henry at Fort Conger" was difficult to comprehend, since Henry was shot at Camp Clay: Brainard would have never made such a labeling error. But comparing several of Brainard's handwritten labels to the items on the abovementioned accession list made it clear that whoever made up the list did not copy Brainard's descriptions word for word. That individual probably had no intimate knowledge of the LFBE and simply assumed that Henry was executed at Fort Conger, which would account for the erroneous wording.

Unfortunately, the .45 cartridge in question and its handwritten tag were separated long ago, and despite several searches by the NMAH's weapons curator, this cartridge cannot be located among so many similar items (K. Golden, pers. comm. 2009).

But the story of the ammunition does not end here, and again, Brainard is at the heart of it. Brainard died in 1946, followed by his second wife in 1953. His stepdaughter, Mrs. Donald L. McVickar (Elinor Guthrie McVickar), had her parents' things shipped from storage in Washington to her New York apartment, but "had to leave some of the Army lockers there because I could not take time away from my office to get in touch with someone who could adquately [sic] appraise them for their historical value" (McVickar to Davis, 11 July 1954, in Brainard, 1870-1961).

In September 1954, Mrs. McVickar wrote to Mr. Seymour J. Pomerenz of the Army's Adjutant General's Office and related an intriguing experience:

Upon opening the carton of [Brainard's] personal possessions which I had sent up from the storage company the day I was in Washington, I came across a small silver vegetable dish, wrapped up. Inside of it was a long, narrow notebook containing the pencilled diary which General Brainard had kept during the Greeley [sic] Expedition. The entries were made in 1884 [this was No. 11 field notebook]. I am mystified about this most of it I could not read. But I thought I'd better send 
it to you, owing to the very secrecy with which the diary was packed.

McVickar then indicated the diary would be mailed to Pomerenz, so that he and Dr. Dallas D. Irvine, chief archivist for the War Records Branch of the National Archives, might examine it. She added an equally intriguing postscript:

P.S. It is questionable whether I can send them through the mail, but there are two bullets, which I have a feeling may be tied up with the whole episode-perhaps from the execution of the man who stole the food.

(McVickar to Pomerenz, 13 September 1954, in Brainard, 1870-1961)

The "bullets" to which McVickar referred must have been live ammunition (i.e., cartridges), otherwise she would not have questioned whether they could be sent through the mail.

In December 1955, Major General John A. Klein, the Adjutant General, wrote to McVickar about the disposition of Brainard's papers and other possessions that she had donated. The Arctic journals and field notebooks went to the Army records of the National Archives, but General Klein specifically notes that his office had not received a "long, narrow notebook containing the pencilled diary." In fact, the diary was never sent, as McVickar replied to General Klein in March 1956 that, "I have found the diary to which I referred in our previous correspondence and will bring it with me [during a trip to Washington from New York], with the view of perhaps having a meeting with Dr. Irvine, if you could arrange that for me" (Klein to McVickar, 28 December 1955 and McVickar to Klein, 3 March 1956, in Brainard, 1870-1961).

All but one of the field notebooks went to the National Archives, the exception being No. 11, which eventually ended up at the Dartmouth College Library. However, the label for No. 11, on which the text "No. 11. From March 1st 1884 to June 21st 1884" is written in Brainard's hand, was found by the author among the Brainard Papers at the National Archives. In a 1940 interview, Brainard made reference to still having the field notebooks in his possession (Buchalter, 1940), so at some point, he must have separated out the No. 11 notebook and secretly wrapped it up in the silver vegetable dish, along with the two "bullets."

So what happened to the mysterious "bullets"? Nothing more has been found out about them, and without examining these artifacts, there is no way to determine their caliber(s), or indeed whether they were rifle and/or revolver cartridges.

In a note to the editor of The Outpost of the Lost (1929), Brainard clarified the reference to there being only one serviceable rifle available in camp and added other details that match those from Copley:

As the only serviceable rifles in the camp were of different calibers, the usual military procedure of loading with two ball and one blank cartridge was not followed in the execution of Private Henry. Therefore Frederick, Long and myself agreed that one of our number only should fire. I have sometimes been asked which of us that was. My answer has always been that all three were equally responsible. We were, but actually the three of us took an oath before the event never to tell on this earth who fired the shots. Frederick and Long are dead. They never told who shot Henry and I never shall.

(Brainard, 1929:292)

When Brainard was interviewed in the years following, he consistently recounted the same details, adding in 1935 that after the oath, "the gun was passed from one to another, each swearing as he held it he wouldn't tell who had fired the shot" (Anon., 1935; Fox, 1936; Brainard, 1870-1961: 19 March 1940; Hazen, 1941).

The four rifles retained from Fort Conger can be identified and accounted for between August 1883 and June 1884; two were Springfield Model 1873 Trapdoor .45-70 caliber rifles. A Springfield was used to mark a food cache in November 1883, on the way back from Cape Isabella, but could not be located during a search in April 1884 (the Remington rifle mentioned below was carried during the search) (Greely, 1888, Vol. 1). On 29 April, Greenlander Jens Edward drowned while hunting with Long, and Brainard wrote that the "Springfield rifle- our best weaponwas lost" (Greely, 1888, Vol. 1:511).

Kislingbury (29 April 1884) noted in his journal: "No rifle left now but my two - one shot-gun." One rifle was the "specially designed" single-shot Remington Rolling Block .45-70 caliber rifle presented to Kislingbury by a member of the arms firm (Todd, 1961; Guttridge, 2000), and the other a Winchester Model $1873.44-40$ caliber repeating rifle. Like the Springfield, the Remington was a breech-loading weapon, while the Winchester had a lever-action, holding 15 cartridges in a tube magazine. Nothing is known about the brand or gauge of the shotgun, which would not have been standard Army issue.

Kislingbury was a hunter until at least 11 April (Greely, 1894), but his April-May journal entries indicate that physical weakness kept him from hunting (Kislingbury, 188384), and he died on 1 June.

Notably, three days after Jens Edward drowned on April 29, Henry wrote that "Fredericks is made a hunter and the arrangement is for one, Long or him, to be out by day and night, in order to not loose [sic] a chance of catching a seal on the ice" (Henry, 2 May 1884:60). At that time of year in the Arctic, there was plenty of sunlight for hunting 24 hours a day.

In writing to Brigadier General William B. Hazen, the chief signal officer, on 19 August 1884, a Detroit insurance and real estate agency representing Kislingbury's estate inquired after his private effects and papers and the rifles. In his reply four days later, Hazen wrote about "the rifles referred to, and which it appears were brought back from the Arctic regions, but were not among the effects 


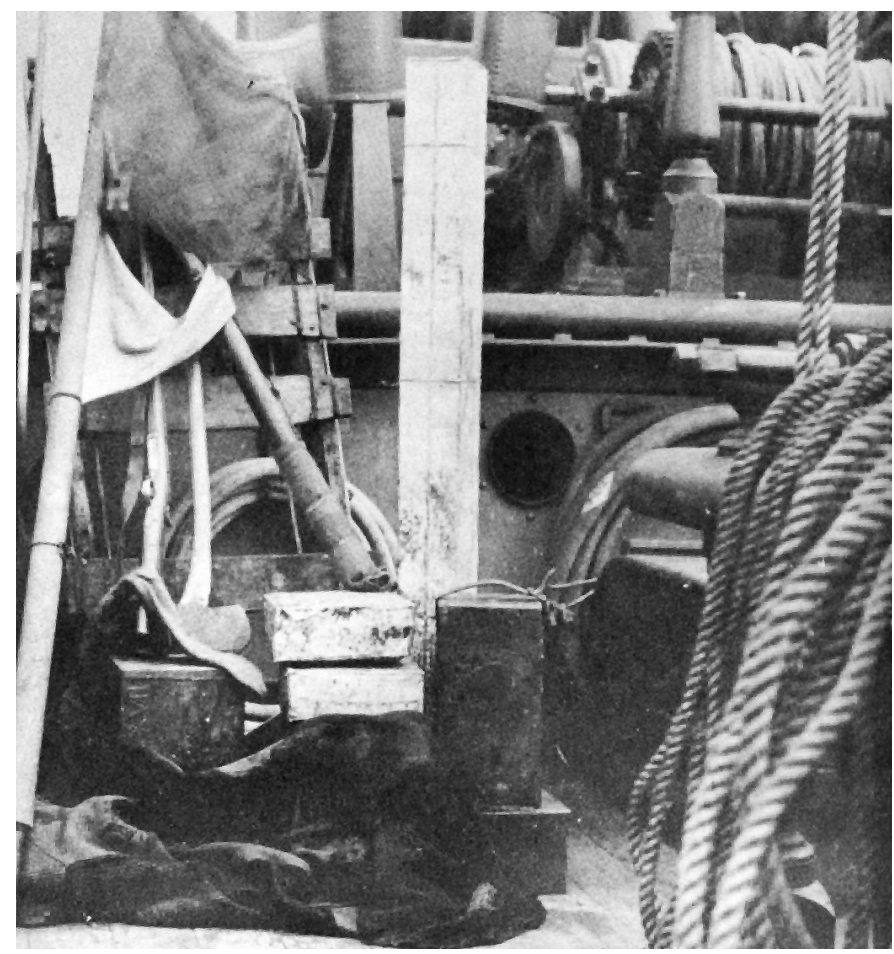

FIG. 7. LFBE relics on board the rescue ship USS Thetis; the rifle and axe are beside one another on the left (NARA).

transferred to this office by Col. A.J. Perry, Deputy Q.M.G. [Quarter Master General]" (Greely Papers, 1844-1935, Container 66, folder dated 13-26 August 1884).

The Remington survives, having been sold at auction in 2003; its serial number was listed as "??866" and it appears that the first two digits are unreadable because of age and wear (Bonhams \& Butterfields, 2003). A National Archives photograph of LFBE relics taken on board the USS Thetis after the rescue includes a rifle, which appears to be the Remington (Fig. 7; Todd, 1961). There is also a crude drawing of these relics in The Rescue of Greely (Schley and Soley, 1885).

The Winchester ended up with Julius Frederick and was passed down through his family until it was sold and donated to the Indiana Historical Society in 2003 (Frederick, 1874-1978). The serial number is difficult to read, and may be 3339 or 5339, both of which indicate a manufacturing date of 1875 (Madis, 1981).

So which rifle was used to kill Henry? According to Todd's writings, Brainard and Frederick met Long as he returned from hunting, and then Brainard and Long went down to the old hut. Obviously, Long was the "day" hunter, and this implies that whichever rifle Long had was the same one used to kill Henry at 2 p.m. Circumstantial evidence therefore points to the Remington $.45-70$ caliber as being the execution weapon, since Frederick must have been the "night" hunter and was in possession of the Winchester after the rescue.

Besides the four rifles and two shotguns taken with the retreating party, Brainard's inventory of many items taken includes a box with "5 Colt's revolvers, 45 cal."
(Brainard, 1881-84). In addition, Greely carried Lieutenant Lockwood's "favorite revolver, as [Lockwood] wore another which he had invariably carried in the field" (Greely, 1894:435; Brainard, 1929:42). Brainard donated this revolver and its accompanying leather holster to the NMAH: "REVOLVER AND HOLSTER, carried by Lockwood to the farthest North which was reached May 13th., 1882." At some point, someone added to this entry on the list, "CAL .44 COLT ARMY REVOLVER - 1871-75)," but this information is in error. Both items have more modern identification tags (Brainard, 1938).

An unknown number of revolvers were left behind at Fort Conger, and these were noted by Robert E. Peary during his first visit to that place in January 1899. In his diary for 11 January 1899, Peary wrote, "Lard, beef extract and revolvers located today" (Stafford, n.d.). Weapons and ammunition were found in perfect condition, and upon Peary's return to the fort that April, they were boarded up in the transit house and the photographer's house (Peary, 1899).

In 1874, the Army replaced its standard sidearm, the Colt 1860 cap and ball .44 revolver, with the metallic-cartridge Colt .45 Single-Action Army, the well known "Peacemaker." This weapon was also available in Colt .44, Rimfire .44, and Winchester .44-40 calibers, but only in small quantities. By 1881, the Army had procured over 20000 standard Colt .45 revolvers (Parsons, 1950). The LFBE would have simplified its ammunition logistics by avoiding "oddball" cartridges, so that the Colt .45 would have been the standard issue. It is most likely that Kislingbury's commercial Winchester .44-40 rifle was the expedition's only firearm in that caliber, and he would have brought his own cartridges. The expedition's standard army cartridges would have been .45-70 for the Springfields (also fitting Kislingbury's Remington) and Colt .45 for the revolvers.

One additional artifact in the Brainard Collection points to the Colt .45 revolvers at Camp Clay: a Colt .45 caliber revolver cartridge shell (Brainard, 1938). With .45 caliber sidearms present in camp, a plausible suggestion was made to the author that a revolver may have been kept as a backup during the execution or to administer the coup de grace (D. Damkaer, pers. comm. 2006).

The rifles weren't the only weapons featured in Copley's writings. When faced with certain death, Henry spied an axe close at hand and sprang for it. Besides the rifle, an axe was one of the objects in both the photograph of LFBE relics aboard Thetis (Fig. 7) and the drawing in Schley and Soley (1885).

\section{THE EXECUTIONERS' MOVEMENTS}

The movements of the three sergeants prior to the execution, as described in Copley's account, are comparable to those described in Todd's writings. As related in Copley, it makes sense that Frederick was the sergeant who objected to killing Henry by stealth, since he was "a man of feeling" 
and (in contrast to Long) did little hunting. And as Todd notes, this is undoubtedly when "the trio seemed by their gestures to be engaged in a dispute." According to Todd, Greely later learned that the dispute "had been caused by the insistence of one of the men that he would not be party to killing Henry by stealth, no matter how much stronger he was than his executioners" (Todd, 1961:243). In addition, because of his quiet and unassuming ways, Frederick was the perfect choice to lure Henry down to the old hut, where Brainard and Long were lying in wait.

"At least one of the sergeants had no more compunction about killing him than he would have had about killing a mad dog," wrote Copley. This was Brainard. His statements with very similar wording appeared in interviews many years later: "I would have no more compunction shooting a man who was stealing from the starving than in shooting a wolf" (Anon., 1935), and "I would have shot him myself as gladly as I would have shot a wolf" (Buchalter, 1940).

In 1898, Brainard had cause to question whether Long would reveal the identity of the executioner. At that time, Brainard was a captain in the Commissary and Subsistence Corps, preparing to depart Vancouver Barracks (Washington state) on a relief expedition for Alaskan miners. Long was employed by the U.S. Weather Bureau in New York City, while Frederick was serving in a similar capacity in Indianapolis. In February of that year, Brainard wrote to Frederick that Long was in an "ugly temper": "Long feels that he has not received as much [recognition] as the others and wishes to air his troubles through the newspapers. If he does, it will be best not to notice him in any way, and the matter will die out at once" (Brainard to Frederick, 8 February 1898 in Frederick, $1874-1978)$.

On 21 June 1914, the day before the five remaining LFBE survivors were to meet at the New York Club on the 30th anniversary of their rescue (Anon., 1914), the Times ran a story in which Long recounted the expedition in some detail, but without a single mention of Henry or the execution. Two years later, Long was dead from a stroke (Anon., 1916; Guttridge, 2000).

\section{HENRY'S BODY}

After the execution, Greely indicated that Henry's body would be interred at the foot of the northern ice field (Fig. 8). The discovery and subsequent history of Henry's remains fosters a mystery in itself.

Schley and Soley (1885) relate that Henry's remains were found by accident on the night of the rescue, after Lieutenant (junior grade) John C. Colwell and Ice Master Frank Ash (both of the Bear) had strolled down to the hut around midnight:

Looking out from the side of the hut to the ice-foot, [Colwell's] attention was fixed by a dark object outlined on the white snow. Following a path which led to it from where he stood, Colwell found the mutilated remains

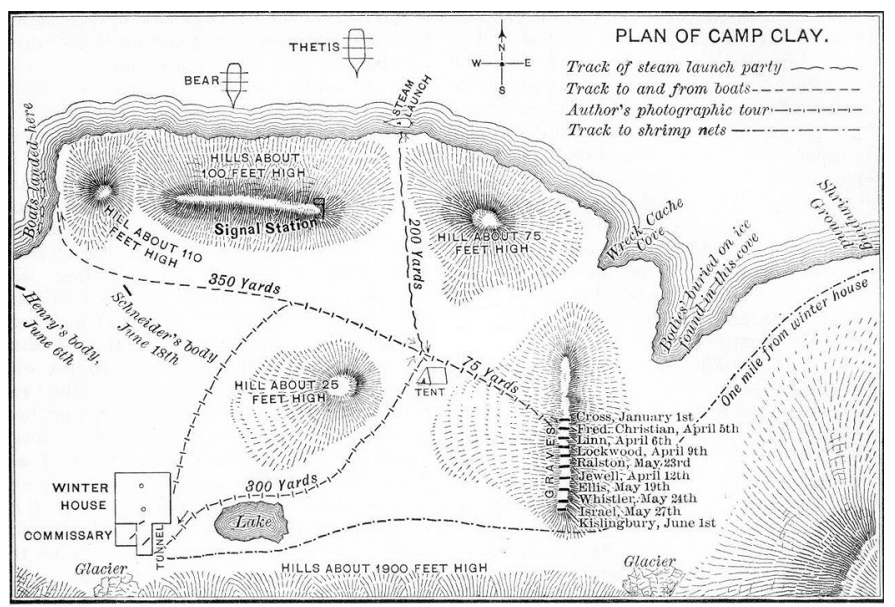

FIG. 8. Plan of Camp Clay at the time of rescue. Note that the distances do not appear to correlate to one another (Harlow, 1885).

of a man's body. It was afterwards identified from a bullet-hole as that of Private Henry, who had been executed on the $6^{\text {th }}$ of June. Wrapping it up in a blanket, Colwell carried it to the landing-place, where a seaman took the bundle on his shoulder. Presently the boat came off, and all who had remained on shore were taken on board the Bear.

(Schley and Soley, 1885:236)

Schley and Soley (1885) state that Colwell recognized his own uniform coat (which Greely had salvaged from the wreck of the relief ship Proteus) among confused heaps of clothes at the winter hut. This item of clothing can be matched to the hitherto unknown chronicler of a journal written on the Bear and held by the Naval History and Heritage Command: "Found my uniform...Walked down to ice foot to look for more bodies, as they said some were buried in the ice. Found the bones of a large man about $75 \mathrm{yds}$ from hut, no head. Tied him up and took on board" (Anon., 22 June 1884a:24).

The location of the bullet hole on the remains was not noted in the records, but since Henry was shot in the chest and head, and his headless remains were recovered, the chest area seems the only logical location. At least a partial explanation for the missing head may be found in the fact that Henry was shot with a large caliber weapon that would have caused extensive damage to the skull or neck or both, depending on the area and angle of the bullet's impact. Further damage could have been caused by the body's removal to the ice foot, since it is likely, given the others' physical condition, that they dragged the body to that location.

Greely (1894) made a verbal report regarding the execution to his departmental superiors several days before Henry's burial in Cypress Hills National Cemetery, Brooklyn. He then wrote to the Adjutant General of the Army R.C. Drum from Portsmouth, on 11 August 1884, to report Henry's execution and request that a court of inquiry be ordered or a court martial convened regarding the matter. Drum responded on 14 November 1884: 
I have the honor to inform you that upon consideration of your report, in connection with extracts from the diaries of the several members of the Lady Franklin Bay Expedition, and also in connection with the diary of Private Henry himself, the Secretary of War entertains no doubt of the necessity, and the entire propriety of your action in ordering the execution of Private Henry, under the circumstances and in the manner set forth in your report.

(Greely, 1888, Vol. 1:364)

When Brainard originally filed his journal with the War Department, it contained entries only up to 8 August 1883, so Drum could not have consulted Brainard's journal beyond that date before replying to Greely on 14 November 1884 (Brainard, $1881-84$ ).

Officially, Henry's remains were buried with full military honors. No family or friends were present, but as rumors spread that Henry's true cause of death was not starvation, someone who claimed to be his sister (Dora Buck) requested an exhumation and an autopsy; however, this never materialized (Guttridge, 2000). What we are left with today are cemetery records, which show the following: "Henry, Charles B, PVT E T US CAV, Plot: 3912, bur. 08/09/1884" - "Died of Starvation" (Interment.net, 19972011; Guttridge, 2000:319).

What additional questions (and answers) regarding an Arctic execution lie buried in plot 3912 ?

\section{ACKNOWLEDGEMENTS}

This paper is dedicated to the late Leonard F. Guttridge and to Dr. David M. Damkaer, in appreciation of their assistance, kindness and encouragement. I am especially indebted to Kathleen Golden, in addition to D.E. Haberstich, J.L. Jones, D.E. Kloster, Dr. S. Loring, and D. Miller of the National Museum of American History, and Marjorie Ciarlante and A.B. House Jr. at the National Archives and Records Administration. My warmest thanks to Constance White at the Marathon Area Historical Society, J. Ferrell of Bonhams \& Butterfields, and R. Marcot and M. Strietbeck of the Remington Society of America. P.N. Cronenwett, S. Hartwell, and B. Krieger at the Dartmouth College Library cheerfully attended to my every request, as did J.E. Baldwin and Dr. D. Sartain at the Explorers Club, and B. Caldwell and E.L. Mundell of the Indiana Historical Society. My thanks also to E.R. Brainard, M.D. Brainard, Dr. L.C. Bruno and staff (Manuscript Division, Library of Congress), J. Foley (Montana Historical Society), J.A. Greene, P. Hlinka, M.A. Kane (Cortland County Historical Society), J. Kobalenko, D. Kosman (Little Big Horn Associates, Inc.), J.D. Mackintosh, Manchester Public Library, J.F. McConnell, Naval History and Heritage Command (Washington Navy Yard), The New York Public Library, Orange County Public Library (Florida), M. Rosewitz (U.S. Army Communications-Electronics Museum), Seminole County Public Library (Florida), U.S. Army Reserve Personnel Center, Dr. H. Vogel, and L. Waterman. My thanks to the three anonymous reviewers for their helpful and detailed comments.

\section{REFERENCES}

Anon. 1880. Army and Navy Journal. 22 May and 5 June.

1884a. Typed transcription of a journal kept on the USS Bear (27 April-15 July 1884), Greely Relief Expedition. Available at National Museum of the United States Navy, Naval History \& Heritage Command, 805 Kidder Breese Street SE, Washington Navy Yard, Washington, D.C. 20374.

. 1884b. Greely's dead comrades. The New York Times, August 9.

-1884c. How Private Henry was shot. Fort Wayne Sunday Gazette, September 7.

- $1884 \mathrm{~d}$. The shooting of Henry. The New York Times, September 8 .

. 1884e. Private Henry's record. The New York Times, September 12.

- 1904. Sergeant Frederick, Arctic explorer, dead. The Indianapolis News, January 7.

_ 1906. Arctic club lauds Peary. The New York Times, December 19.

- 1914. Greely survivors meet tomorrow. The New York

Times, June 21.

- 1916. Francis Long dead. The New York Times, June 9.

- 1935. Polar execution secret well kept. San Antonio Express, October 13.

Barr, W. 1985. The expeditions of the first International Polar Year, 1882-83. Technical Paper 29. Calgary, Alberta: Arctic Institute of North America.

Benét, S.V. 1862. A treatise on military law and the practice of courts-martial. New York: D. Van Nostrand.

Biederbick, H. 1883-84. Contemporary copy of journal. In: Records of the Weather Bureau, (Record Group 27), 1735-1979, 27.4.5. Records of the Lady Franklin Bay Expedition, 1881-84, Journals and diaries, 1881 -85. Available at National Archives at College Park, 8601 Adelphi Road, College Park, Maryland 20740.

Bonhams \& Butterfields. 2003. Sale 7480A, lot 1134, Antique Arms \& Armor and Modern Sporting Guns. 9-10 December.

Bonney, O.H., and Bonney, L.G. 1970. Battle drums and geysers: The life and journals of Lt. Gustavus Cheyney Doane, soldier and explorer of the Yellowstone and Snake River regions. Chicago: Swallow Press Inc.

Brainard, D.L. 1870-1961. The papers of David L. Brainard. STEM 189. Available at Rauner Special Collections Library, Dartmouth College Library, Hanover, New Hampshire 03755.

- 1881-84. Brainard Papers. RG 200, RG 27. Available at National Archives at College Park, 8601 Adelphi Road, College Park, Maryland 20740.

. 1929. The outpost of the lost: An Arctic adventure. Edited by B.R. James. Indianapolis: The Bobbs-Merrill Company.

—. 1938. Brainard Collection. Accession No. 149546. Available at Collection of Armed Forces History, National Museum of American History, Independence Avenue and 1st Street, SE, Washington, D.C. 20003.

1940. Six came back: The Arctic adventure of David L. Brainard. Edited by B.R. James. Indianapolis: The BobbsMerrill Company. 
Buchalter, H. 1940. The wild flowers ruined the record. The Washington Daily News, August 19.

Case, T.S., ed. 1880-81. The Howgate Expedition to Lady Franklin Bay. The Kansas City Review of Science and Industry 4:685-692.

Copley, F.B. 1910. The measure of human grit: The struggle for the meat. The American Magazine 71:253-263.

- 1911a. The measure of human grit: A traitor's death in the Arctic. The American Magazine 71:330-339.

- 1911b. The measure of human grit: The will to live - with death at hand. The American Magazine 71:494-503.

Fox, J.A. 1936. Survivor of Greely band spry at 79. The Sunday Star (Washington), February 23.

Franklin, J. 1824. Narrative of a journey to the shores of the polar sea, in the years 1819-20-21-22, Vols. 1 and 2. London: John Murray.

Frederick, J.R. 1874-1978. Julius R. Frederick papers. Collection No. M 0806, OM 0411. Available at Indiana Historical Society, 450 West Ohio Street, Indianapolis, Indiana 46202.

Greely, A.W. 1844-1935. Papers of Adolphus Washington Greely. Available at Library of Congress, 14th Street and Constitution Avenue NW, Washington, D.C. 20560.

- 1884a. Handwritten order of 5 June. LFBE, Stef Mss 64, Box 2, Folder. Available at Rauner Special Collections Library, Dartmouth College Library, Hanover, New Hampshire 03755. - 1884b. Handwritten order of 6 June. LFBE, Stef Mss 64, Box 2, Folder. Available at Rauner Special Collections Library, Dartmouth College Library, Hanover, New Hampshire 03755.

- 1888. Report on the proceedings of the United States Expedition to Lady Franklin Bay, Grinnell Land, Vols. 1 and 2. Washington, D.C.: Government Printing Office.

. 1894. Three years of Arctic service: An account of the Lady Franklin Bay Expedition of 1881-84 and the attainment of the farthest north. New York: Charles Scribner's Sons.

Guttridge, L.F. 2000. Ghosts of Cape Sabine: The harrowing true story of the Greely expedition. New York: G.P. Putnam's Sons.

Harlow, C.H. 1885. Greely at Cape Sabine: Notes by a member of the relief expedition. The Century Illustrated Monthly Magazine 30 (New Series. Vol. 8):77-90.

Hazen, D.W. 1941. And only six came back. The Sunday Oregonian, January 19.

Henry, C.B. 1883 - 84. Contemporary copy of journal. In: Records of the Weather Bureau, (Record Group 27), 1735-1979, 27.4.5. Records of the Lady Franklin Bay Expedition, 1881-84, Journals and diaries, 1881-85. Available at National Archives at College Park, 8601 Adelphi Road, College Park, Maryland 20740.

Interment.net. Cemetery records online. 1997-2011. www. interment.net/data/us/ny/kings/cypressnat/index_hehi.htm.
Kislingbury, F. 1883-84. Contemporary copy of journal. In: Records of the Weather Bureau, (Record Group 27), 1735-1979, 27.4.5. Records of the Lady Franklin Bay Expedition, 1881 -84, Journals and diaries, 1881-85. Available at National Archives at College Park, 8601 Adelphi Road, College Park, Maryland 20740.

Lanman, C. 1893. Farthest north. New York: D. Appleton and Company.

Lazell, E.W. 1920. The psychology of war and schizophrenia. The Psychoanalytic Review: A Journal Devoted to Understanding Human Conduct 7:224-245.

Mackintosh, J.D. 2002. Custer's southern officer: Captain George D. Wallace, 7th U.S. Cavalry. Lexington, South Carolina: Cloud Creek Press.

Madis, G. 1981. The Winchester handbook. Brownsboro, Texas: Art \& Reference House.

Parsons, J.E. 1950. The Peacemaker and its rivals: An account of the single action Colt. New York: William Morrow.

Peary, R.E. 1899. Peary's latest Arctic work: His own account of his visit to Greely's old camp. McClure's Magazine 14(1):235-240.

Powell, T. 1960. The long rescue. Garden City: Doubleday \& Company, Inc.

Price, G.F., comp. 1883. Across the continent with the Fifth Cavalry. New York: D. Van Nostrand.

Rice, G. 1884. Contemporary copy of journal. In: Records of the Weather Bureau, (Record Group 27), 1735-1979, 27.4.5. Records of the Lady Franklin Bay Expedition, 1881-84, Journals and diaries, 1881-85. Available at National Archives at College Park, 8601 Adelphi Road, College Park, Maryland 20740.

Schley, W.S., and Soley, J.R. 1885. The rescue of Greely. New York: Charles Scribner's Sons.

Schneider, R.R. 1884. Contemporary copy of journal. In: Records of the Weather Bureau, (Record Group 27), 1735-1979, 27.4.5. Records of the Lady Franklin Bay Expedition, 1881-84, Journals and diaries, 1881-85. Available at National Archives at College Park, 8601 Adelphi Road, College Park, Maryland 20740.

Stafford, M.P. n.d. Fort Conger re-discovered (typescript). File No. ACC 807H.292. Available at U.S. Army CommunicationsElectronics Museum, Kaplan Hall Building 275, Fort Monmouth, New Jersey 07703.

Todd, A.L. 1961. Abandoned: The story of the Greely Arctic Expedition 1881-1884. New York: McGraw-Hill Book Company Inc.

Whitney, C., ed. 1904. Men and women of the outdoor world. Outing 45:222-224. 